\title{
The Impact of Excise Tariffs on The Performance of White Cigarette Industry
}

\author{
Indra Tjahaja Amir ${ }^{1}$ \\ Department of Agribusiness \\ Universitas Pembangunan Nasional "Veteran" Jawa Timur \\ Surabaya, Indonesia \\ 1indra_ta@upnjatim.ac.id
}

\author{
Nuhfil Hanani, Syafrial, Abdul Wahid Muhaimin \\ Sosio-Economic Department \\ University of Brawijaya, \\ Malang, Indonesia
}

\begin{abstract}
The aims of this study was a) to analyze the factors that affect the performance of production of white cigarette industry, b) analyze the factors that affect the performance of the consumption and c) simulate, if the government a tax increase of 5 percent or 20 percent of the performance of the industry. The results showed that a) the performance of the production positively affected by the real price of white cigarette and technology. Otherwise, the price of real prices of clove cigarettes, excise tariff and dummy of customs policy negatively affect the production. White cigarette labor and dummy of health policy did not affect the production of white cigarettes, b) the performance of the consumption positively affected by the price, consumption and national income. Otherwise, dummy of excise policy negatively affect consumption changes clove cigarettes. The price of clove cigarette as well as excise rate on cigars and health policy dummy did not significantly affect clove cigarette consumption, and c) Excise instrument very effective role as the main contribution of government revenue and also effectively reducing consumption both clove and white cigarettes. (Abstract)
\end{abstract}

Keywords-customs policy; production; consumption; white cigarette; simulation

\section{INTRODUCTION}

Tobacco industry is still an important role in moving the national economy, especially in the central areas of tobacco, cloves and a little tobacco industry, among others in growing industries/services related, the provision of field operations and employment. In a situation of economic crisis, tobacco industry still able to survive, even the industry is able to contribute significantly in increasing state revenues through tax revenues [1],[2].

Government policies that suffocate to the economic performance of the tobacco were started from issued Law No. 23 of 1992 on the dangers of addictive substances for medical. According to the Tobacco Industry Roadmap Priority that now entering the third phase (2015-2020) is the health aspect beyond the aspect of labor and state revenue perceived impact on farmers and the industry [3]. The intervention of the other institutions and civil society organizations in order to hinder the economic development of tobacco and cigarette ask the government and the legislature to raise the excise tax of tobacco products to the limit of the highest (57\%), which allowed Excise Act No. 39 of 2007.
Government policies that hinder economic performance white cigarette industry is an increase in tobacco taxes that affect to decline the white cigarette production but is followed by increase of imported cigarettes. Indonesian cigarette imports during the years 2005 - 2009 rose $60.41 \%$ [2]. Based on the Tobacco Atlas (2012) Indonesia has the fourth-largest cigarette consumption in the world after China, USA and Russia. Increased Indonesian cigarette consumption per year of $5.16 \%$ from 2003 to 2011 . However, according to Susenas 2010 , the prevalence of smokers tend to increase annually by $6.94 \%$, whereas the Indonesian government targets to reduce the prevalence of smoking by $1 \%$ per year [4].

Reference [3] showed that Government regulation $109 / 2012$ less influence on tobacco farmers. This was shown very little tobacco farmers are switching to other crops, because farmers still believe tobacco is the main crop. In addition, tobacco can be used as raw material for organic insecticide products, veterinary drugs, diabetes drugs, antibodies, cosmetics and biofuels. However, if the effect is implemented on the economic performance white cigarette, whether it has a different effect on the performance of farmers?. This research is considered essential to study the implementation of government policies on the tobacco industry's performance, especially white cigarette.

The objectives of the study was a) to analyze the factors affecting the performance of the production of white cigarettes industry, b) to analyze the factors affecting the performance of the consumption of white cigarette industry, and c) to simulate the increase in the excise policy of 5 percent and 20 percent on the performance of white cigarette industry.

\section{METHOD}

The data used is secondary data for 23 years which includes data on production, import and export, price of cigarettes, the cigarette excise, cigarette consumption, demand for white cigarettes, and population. All data used was obtained from the agencies concerned with the theme of this paper as Indonesian Ministry of Agriculture, the Central Bureau of Statistics of the Republic of Indonesia (BPS), the Directorate General of Customs and Excise, FAOSTAT, institutions related research, and a variety of literature sources more. 
The method using is Two Stage Least Square or 2SLS through data analysis program SAS/ETS version of 9:13 to explain the factors influencing the market of white cigarette industry. To test objective 1 and 2 use a simultaneous equation, consisting of structural equation and the equation of identity. Simultaneous equations of domestic markets of white cigarettes as follows:

1. The equation of production structural of white cigarettes:

$$
\begin{gathered}
\mathrm{QW}=\beta_{0}+\beta_{1} \mathrm{RPQW}+\beta_{2} \mathrm{RPQC}+\beta_{3} \mathrm{~T}+\beta_{4} \mathrm{RWW}+\beta_{5} \mathrm{TE}+ \\
\delta_{1} \mathrm{DEP}+\delta_{2} \mathrm{DHP}+\mathrm{e}
\end{gathered}
$$

2. The equation of supply identity of white cigarettes:

$$
\mathrm{SUS}=\mathrm{QW}-\mathrm{KW}+\mathrm{QXM}
$$

3. The equation of identification market clearing domestic market white cigarettes:

$$
\text { DES }=\text { SUS }
$$

4. The equation of consumption structural of white cigarettes:

$$
\begin{aligned}
& \mathrm{KW}=\beta_{0}+\beta_{1} \mathrm{RPQC}+\beta_{2} \mathrm{RPQW}+\beta_{3} \mathrm{QC}+\beta_{4} \mathrm{QW}+\beta_{5} \mathrm{TE}+ \\
& \beta_{6} \mathrm{RGDP}+\beta_{7} \mathrm{POP}+\delta_{1} \mathrm{DEP}+\delta_{2} \mathrm{DHP}+\delta_{3} \mathrm{LKW}+\mathrm{e}
\end{aligned}
$$

Analysis of policy simulations used to test the objective 3 , the scenario tobacco excise policy by 5 percent and 20 percent of the performance of white cigarette industry.

Where :

QC = Production of clove cigarettes

$\mathrm{QW}=$ Production of white cigarettes

RPQC = real price clove cigarettes

RPQW = real price of white cigarettes

$\mathrm{TE} \quad=$ Tariff excise on tobacco products

$\mathrm{T}=$ Technology

RWW $=$ Real wage labor of white cigarettes

RGDP $=$ Real GDP

POP $=$ Total population

SUS = Supply of white cigarettes

QMS = Import of cigarettes

LRPQW = Lag real price of white cigarettes

DES = Demand of white cigarette

KW = Consumption of white cigarettes

LKW = Lag white cigarette consumption

DEP = Dummy Excise Policy, 2007

DKC $=0$, using the ad valorem excise policy (before to 2007)

DKC $=1$, using a specific excise policy (starting from 2007)

DHP = Dummy Government Regulation No. 81 of 1999 on Health, 2000

DKK $=0$, using the health policy (before to 2000)

DKK $=1$, using the health policy (starting from 2000)

\section{RESULTS AND DISCUSSION}

\section{A. White Cigarette Production}

The results of parameter estimation white cigarette production is shown in Table 1 . Table 1 showed that the criteria of estimation equation white cigarette production shows the coefficient of determination (R2) of 0.80020 . It can be said that the explanatory variables that build the model is able to explain the variable endogenousnya by 80.02 percent, while 19.98 percent is explained by other factors outside the model. The value of $F$ statistic of 8.01 with probability $\alpha=$ 0.0005 , it means the explanatory variables of the equation white cigarette production are simultaneously able to explain properly the behavior of white cigarette production in Indonesia

White cigarette production behavior were positively influenced by the real price of white cigarette and technology. Instead the price of real producer prices of clove cigarettes, excise tariff and excise policy dummy were negatively affect

\begin{tabular}{|c|c|c|c|c|}
\hline No & $\begin{array}{c}\text { Explanatory } \\
\text { variables }\end{array}$ & $\begin{array}{c}\text { Parameter } \\
\text { Estimate }\end{array}$ & T test & ESR \\
\hline 1. & Intercept & 45.89041 & $3.62 \mathrm{~A}$ & \\
\hline 2. & $\begin{array}{l}\text { The Real Price of } \\
\text { White Cigarettes } \\
\text { (RPQW) }\end{array}$ & 0.003434 & $2.27 \mathrm{~A}$ & 0.0667 \\
\hline 3. & $\begin{array}{l}\text { The Real Price of } \\
\text { Clove Cigarettes } \\
\text { (RPQC) }\end{array}$ & -0.02503 & $-3.29 \mathrm{~A}$ & -0.3072 \\
\hline 4. & Technology (T) & 2.796752 & $2.94 \mathrm{NS}$ & 0.1560 \\
\hline 5. & $\begin{array}{l}\text { Real Wage Labor of } \\
\text { White Cigarettes } \\
\text { (RWW) }\end{array}$ & 1.045150 & $0.91 \mathrm{NS}$ & 0.0131 \\
\hline 6. & $\begin{array}{l}\text { Cigarette Excise Tariff } \\
\text { (TE) }\end{array}$ & -0.82330 & $-1.32 \mathrm{C}$ & -0.1097 \\
\hline 7. & $\begin{array}{l}\text { Dummy Excise Policy } \\
\text { (DEP) }\end{array}$ & -13.6385 & $-1.56 \mathrm{C}$ & -0.0138 \\
\hline 8. & $\begin{array}{l}\text { Dummy Health Policy } \\
\text { (DHP) }\end{array}$ & -7.04926 & $-0.65 \mathrm{NS}$ & -0.0171 \\
\hline
\end{tabular}
white cigarette production. White cigarette labor and health policy did not affect the changes of white cigarettes production.

TABLE I. PARAMETERS AND ELASTICITY OF WHITE CIGARETTE PRODUCTION

Notes $:$ ESR = Elasticity Short Term $\quad$ ELR = Elasticity Long Term A showed significantly different test level of 5 percent B showed significantly different test level of 10 percent C showed significantly different test level of 20 percent D showed significantly different test level of 30 percent NS indicates not significan

Source: Author's analysis

White cigarette production behavior as shown Table 1 can be explained as follows:

a. Parameter real price of white cigarette showed a positive and significant effect on the level of 5 percent test to the changes in the production of white cigarettes. It means that the higher the price, the white cigarette production will be even greater. Elasticity of short-term of real price white cigarette to the production of white cigarettes is inelastic of 0.0667 , it means that the real price of tobacco is less 
responsive to the changes in the production of white cigarettes. Short-term elasticity of white cigarette production last year of 0.0667 is if the real price of cigarettes increase 10 percent, so white cigarette production will increase by 0.66 percent.

b. Parameter real price of clove cigarettes indicated a negative and significant effect on the level of 5\% test to the changes in the white cigarette production. It means that if the price clove cigarettes increases, so the cigarette producer will increase clove cigarette production as a substitute white cigarette production. Elasticity of shortterm showed results inelastic. Elasticity of short-term production of white cigarettes on the wages of labor is inelastic at -0.3072 , it means clove cigarette prices less responsive to changes in the production of white cigarettes. Understanding of short-term elasticity of white cigarette production of -0.3072 is if the labor costs decrease in by 10 percent, so the white cigarette production will raise by 3.07 percent.

c. Technological parameter has influence a positive and significan on the $t$ level 5 percent test to the changes of white cigarette production. It means, if the more advanced technology used, the tobacco companies will increase production of white cigarettes, and vice versa. Elasticity of short-term production of white cigarettes is 0.1560 , it means if technology increase of 10 percent, it will increase the production of white cigarettes of 1.56 percent.

d. Cigarette excise tariff parameters showed a negative influence and significant on white cigarette production changes. It means that high cigarette excise tariff proven to reduce the production of white cigarettes. Short-term elasticity of cigarette excise tariff on production of white cigarettes is inelastic, 0.1097 , it means cigarette excise tariff is less responsive to changes in the production of white cigarettes. Understanding of short-term elasticity white cigarette production of 0.1097 is if excise tariff increases 10 percent, will increase the production of white cigarettes of 1.09 percent.

e. Excise Policy Parameter visible effect a positive on changes white cigarettes production. It means that excise policy with specific systems capable of generating higher state revenues through increased production of cigarette excise compared to an ad valorem system. Elasticity of short-term of excise policy is inelastic, it means the excise policy are less responsive to changes in the production of white cigarettes. The results of this study are in line with [7],[12].

Implementation of government policies on the performance of white cigarettes can be seen from the behavior of white cigarette production. Policies that encourage the performance of commodity white cigarette that is by increasing the price of white cigarette and technology. While policies that hinder the performance of white cigarettes is rising commodity prices clove cigarettes, because the clove cigarette is a substitute of white cigarettes. Besides the excise policy and the policy about the dangers of smoking to health may hamper economic performance white cigarette.

\section{B. Supply of White Cigarette}

Supply of white cigarette is identity equation which is the sum of the production of cigarettes and cigarette imports after deducting cigarette consumption. Equation identity of cigarette deals can be formulated as follows: SUS = QSPM $\mathrm{KSP}+\mathrm{QXM}$, where SUS is white cigarette, KSP is the consumption of white cigarettes, and QMS is the number of white cigarette imports.

The identity equation states that supply of white cigarettes desperately need the supply of white cigarette production quantities produced and net export import white cigarette. If one of these suppliers change then affects the supply of white cigarettes.

\section{Market Clearing of The Domestic White Cigarette}

Market clearing of the domestic white cigarette is the identity equation which states that the demand for white cigarettes equal to supply for white cigarette. Identity equation of market clearing of the white cigarette can be formulated as follows: DES = SUS, where DES is white cigarette demand, SUS is white cigarette supply.

The identity equation states hat the demand of the white cigarette is determined from the components of productions, exports, imports and total stock of white cigarettes. If one of the components change, so it will affect the number of white cigarette demand.

\section{White Cigarette Consumption}

The results of parameter estimation white cigarette consumption is shown in Table 2. Table 2 shows that the coefficient of determination (R2) is 0.99784 . It can be said that the explanatory variables that build the model is able to explain the variable endogenousnya by 99.78 percent, while 0.22 percent is explained by other factors outside the model. Judging the value of $F$ statistic of 555.54 with probability $\alpha$ is larger than 0.0001 , it means explanatory variable of the equation white cigarette consumption are simultaneously able to explain properly the behavior of white cigarette consumption in Indonesia.

White cigarette consumption positively influenced by the number of population, health policy dummy and white cigarette consumption last year. Conversely production of clove cigarettes and cigarette excise tariff influences negatively on consumption changes white cigarettes. The prices of white and clove cigarette, white cigarette production, GDP and excise policy dummy did not affect significantly on the changes in consumption of white cigarettes. The results of this study are in line with [8] study. 
TABLE II. PARAMETERS AND ELASTICITY OF WHITE CIGARETTE PRODUCTION

\begin{tabular}{|c|c|c|c|c|c|}
\hline No & $\begin{array}{c}\text { Explanatory } \\
\text { variables }\end{array}$ & $\begin{array}{c}\text { Parameter } \\
\text { Estimate }\end{array}$ & T test & $E R S$ & $E L S$ \\
\hline 1. & $\begin{array}{l}\text { The Price Real of } \\
\text { Clove Cigarettes } \\
\text { (RPQC) }\end{array}$ & $-0,00292$ & -0.56 & $-0,046$ & $-0,112$ \\
\hline 2. & $\begin{array}{l}\text { The Price Real of } \\
\text { White Cigarettes } \\
\text { (RPQW) }\end{array}$ & 0,007825 & 0.40 & 0,171 & 0,411 \\
\hline 3. & $\begin{array}{l}\text { Production of } \\
\text { Clove Cigarettes } \\
\text { (QC) }\end{array}$ & $-0,07094$ & -2.94 & $-0,638$ & $-1,533$ \\
\hline 4. & $\begin{array}{l}\text { Production of } \\
\text { White Cigarettes } \\
\text { (QW) }\end{array}$ & 0,046229 & 1.05 & 0,066 & 0,160 \\
\hline 5. & Excise Tariff (TE) & $-0,12093$ & -1.41 & $-0,197$ & $-0,474$ \\
\hline 6. & $\begin{array}{l}\text { Real GDP } \\
\text { (RGDP) }\end{array}$ & $5,319 \mathrm{E}-7$ & 0.58 & 0,083 & 0,201 \\
\hline 7. & Population (POP) & 0,000093 & 2.86 & 0,952 & 2,287 \\
\hline 8. & $\begin{array}{l}\text { Dummy Excise } \\
\text { Policy (DEP) }\end{array}$ & 3,041962 & 1.36 & 0,032 & 0,077 \\
\hline 9. & $\begin{array}{l}\text { Dummy Health } \\
\text { Policy (DHP) }\end{array}$ & $-3,047409$ & -1.95 & $-0,077$ & $-0,185$ \\
\hline 10. & $\begin{array}{l}\text { Lag Consumption } \\
\text { of White } \\
\text { Cigarettes (LKW) }\end{array}$ & 0,583761 & 3.56 & & \\
\hline
\end{tabular}

Notes $:$ ESR $=$ Elasticity Short Term $\quad$ ELR = Elasticity Long Term

A showed significantly different test level of 5 percent

B showed significantly different test level of 10 percent

C showed significantly different test level of 20 percent

D showed significantly different test level of 30 percent

NS indicates not significant

Source: Author's analysis

White cigarette consumption behavior as shown Table 2 can be explained as follows:

a. Parameter of clove cigarette production has a negative influence on the change in white cigarette consumption. It means if the production of clove cigarettes increases, the white cigarette consumption decreases, and vice versa. Elasticity of short-term production of clove cigarettes to white cigarettes consumption is inelastic (-0.6384), it means the production of clove cigarettes are less responsive to changes in white cigarette consumption. While the long-term elasticity is elastic $(-1.5338)$, it means the production of clove cigarettes are responsive to changes in white cigarette consumption. Short-term elasticity clove cigarette production of -0.6384 , it means if the production of clove cigarettes increase by 10 percent, it would reduce cigarette consumption by 6.38 percent white, but in the long term it will decrease by 15.34 percent.

b. Parameter of white cigarette production shows a positive influence on changes in white cigarette consumption. It means that if the production of white cigarettes increases, the white cigarettes consumption increased, and vice versa. Elasticity of short-term and long-term of white cigarette production to white cigarette consumption is inelastic (0.0667 and 0.1603$)$, it means the production of white cigarettes are less responsive to changes in white cigarette consumption. Elasticity of short-term production of white cigarettes of 0.0667 , it means if the production of clove cigarettes increase by 10 per cent, it will raise white cigarette consumption by 0.67 percent, but in the long run will increase by 1.60 percent.

c. Parameter of cigarette excise tariff shows a negative influence on changes in white cigarette consumption. It means that if the cigarette excise tariff increased, so the price of white cigarettes will increase and lead to white cigarette consumption will decline. Elasticity of short-term and long-term excise tariff to white cigarette consumption is inelastic, each -0.1977 and -0.4749 , it mean cigarette excise less responsive to changes in white cigarette consumption. Understanding of short-term elasticity of 0.1977 cigarette excise is if the cigarette excise increased by 10 percent, then the white cigarette consumption decreased by 1.97 percent, while in the long term decline of 4.75 percent.

d. Parameter number of the population has a positive influence on changes in the consumption of white cigarettes. It means if the population increases, the number of white cigarette consumption increases, and vice versa. Short-term elasticity of the total population of the white cigarette consumption is inelastic 0.9523 , it means the total population is less responsive to changes in white cigarette consumption. While the long-term elasticity is elastic, 2.2879 , it means the population is responsive to changes in white cigarette consumption. Short-term elasticity of clove cigarette production is 0.9523 , it means if population increase of 10 percent, it would raise the white cigarette consumption by 9.52 percent, but in the long run will increase by 22.87 percent.

e. Parameter of health policy has a negative influence on changes in the consumption of white cigarettes. It means health policy causes white cigarette consumers decrease. Elasticity of short-term and long-term consumption of white cigarettes on health policy dummy is inelastic, it means health policy are less responsive to changes in white cigarette consumption. The results of this study are in line with [5], [9].

f. Parameters of white cigarette consumption last year had a positive influence on changes in the consumption of white cigarettes. It means white cigarette consumption last year showed growth indicators white cigarette consumption next year, because if white cigarette consumption last year is positive then white cigarettes consumption will go up next year.

Implementation of government policies on the performance of white cigarettes can be seen from the behavior of white cigarette consumption. Policies that encourage increased consumption of white cigarettes are increased white cigarettes production and reduced clove cigarettes production, because clove cigarettes is a commodity substitution of white cigarettes. Policies that hinder increased white cigarettes consumption are increases the excise and policy about the dangers of smoking for health. 


\section{E. Policy Simulations in Excise Tariff Increase of 5 Percent and 20 Percent}

Policy simulation to increase tobacco excise tariff, are meant to see the impact of these policies on the performance of white cigarettes, especially small and micro enterprises when the government raised excise tariff of $5 \%$ or $20 \%$.

As we know that the tax has a characteristic that is as an instrument to reduce consumption and production of white cigarettes. Therefore, to see the effectiveness of the instruments it needs simulated cigarette excise by comparing the increase in cigarette excise tariff of 5 percent, from the average customs tariff of Rp. 22.05 trillion to Rp. 23.15 trillion and 20 percent, from the average customs tariff of Rp. 22.05 trillion to Rp. 26.46 trillion.

TABLE III. POLICY SIMULATION TOBACCO EXCISE TARIFF INCREASE BY 5 PERCENT AND 20 PERCENT

\begin{tabular}{|l|c|c|c|c|c|c|}
\hline \multirow{4}{*}{ Variable } & \multicolumn{2}{|c|}{$\begin{array}{c}\text { Excise Tariff } \\
\text { Rise 5 Percent }\end{array}$} & \multicolumn{2}{|c|}{$\begin{array}{c}\text { Excise Tariff } \\
\text { Rise 20 } \\
\text { Percent }\end{array}$} & \multicolumn{2}{c|}{$\begin{array}{c}\text { Percent } \\
\text { Change (\%) }\end{array}$} \\
\cline { 2 - 7 } & \multicolumn{7}{|c|}{$\begin{array}{c}\text { Pred } \\
\text { Basic }\end{array}$} & $\begin{array}{c}\text { Pred } \\
\text { Sim }\end{array}$ & $\begin{array}{c}\text { Pred } \\
\text { Basic }\end{array}$ & $\begin{array}{c}\text { Pred } \\
\text { Sim }\end{array}$ & $\begin{array}{c}\text { Rise } \\
\mathbf{5 \%}\end{array}$ & $\begin{array}{c}\text { Rise } \\
\mathbf{2 0} \%\end{array}$ \\
\cline { 2 - 7 } & 75.0 & 73.6 & 75.0 & 72.91 & -1.8 & -2.8 \\
\hline $\begin{array}{l}\text { White } \\
\text { Cigarettes } \\
\text { production }\end{array}$ & 22.5 & 22.2 & 22.5 & 22.03 & -1.0 & -2.1 \\
\hline $\begin{array}{l}\text { White cigarette } \\
\text { consumption }\end{array}$ & 52.4 & 51.3 & 52.4 & 50.87 & $-2,2$ & -3.0 \\
\hline $\begin{array}{l}\text { White } \\
\text { Cigarettes } \\
\text { Imports }\end{array}$ & & & & & & \\
\hline
\end{tabular}

Table 3 showed that the increase in excise tariff by 5 percent has a negative impact on the production of white cigarettes of 1.877 percent. It means that tobacco excise tariff increase by 5 percent reduce the production of white cigarettes of 1.877 percent, reduce white cigarette consumption of 1.042 percent and reduce white cigarette imports of 2.2242 percent. Furthermore, what if the government increases the excise by 20 percent, it is very effective in reducing white cigarette consumption of 2.091 percent. Declining in white cigarette consumption makes the company reduce white cigarette production down up to 2.786 percent and reduce imports and also white cigarette of 3.0850. This proves that the excise instrument plays highly effective reducing the production, consumption and import of white cigarettes or could inhibit economic performance white cigarette.

\section{RESULTS AND DISCUSSION}

Factors that influence positively on the performance of the production of white cigarettes is the real price of cigarettes white, technology, and the interest rate, otherwise the negative effect is the real price of clove cigarettes, and cigarette excise tariff. All of these behaviors responded inelastic in the short term.
Factors that influence positively on the performance of white cigarette consumption is the price of white cigarettes, cigarette consumption and national income, whereas the negative effect is the excise policy. All of these behaviors responded inelastic in the short term and long term.

Based on simulation tariff policy to increase tobacco excise suffocating indicates effectively decrease the performance of the economy of white cigarette. If the government raised the tobacco excise by 20 percent proved to be very effective to reduce production and consumption of white cigarettes doubled compared with 5 percent.

In supporting the improvement of economic performance white cigarette, it is expected the government did not increase excise tariff policy suffocating, which led to increase white cigarette price high, so that affect less profitable for producers and consumers of white cigarettes.

\section{ACKNOWLEDGMENT}

Authors would like to thank the leaders of the university, faculty and department as well as all those involved in this research.

\section{REFERENCES}

[1] Ministry of Industry, Republic of Indonesia,. Roadmap Industri Pengolahan Tembakau 2010 - 2025, Ditjen Industri Agro dan Kimia, Jakarta, 2009.

[2] Ministry of Agriculture, Republic of Indonesia, Outlook Komoditas Pertanian Perkebunan, Pusdatin, Jakarta, 2010.

[3] I.T. Amir, "The Impact of Excise Policy and Government Regulations about The Hazards of Smoking For Health on Tobacco Commodity," Int. J. Agric. Innov. and Res., vol. 3, pp. 2319, 2014.

[4] Afriansyah, "Keragaan Produksi dan Perdagangan Tembakau Cerutu Indonesia di Pasar Internasional," unpublished.

[5] A. Abdillah et al., "Kondisi Petani Tembakau di Indonesia: Studi di Tiga Wilayah Penghasil Utama Tembakau," Kerja sama Lembaga Demografi FEUI dan Tobacco Control Support Center - IAKMI, 2008.

[6] Nota Keuangan dan Rancangan APBN TA 2012 Republik Indonesia, Government of Indonesia, Jakarta, 2012

[7] A. Monika, Mathur, Manu Raj, and S. Neha, "A Framework to Prevent and Control Tobacco among Adolescens and Children: Introduction the IMPACT Model," The Indian J. Pediatr., May 2012.

[8] M. Czubek and S. Johal, "Econometric Analysis of Cigarette Consumption in the UK," [Online], Available: http://www.hmrc. gov.uk/research/ cig-consumption-uk.pdf. [Accessed: 29-Aug-2018].

[9] Indonesian Tobacco Control Network, "Pengendalian Dampak Tembakau Bukan Penyebab Petani Sengsara," [Online], Available: http://indotc1.blogspot.com. [Accessed: 29-Aug-2018].

[10] E. Irawan, "Analisis Dampak Penetapan Cukai Terhadap Industri Tembakau di Indonesia," unpublished.

[11] R.A. Mussgrave, "Public Finance. The New Palgrave Dictionary of Economics," 2nd Edition, is an eight-volume reference work on economics, edited by N. Steven Durlauf and Lawrence E. Blume. Palgrave Macmillan, 2008.

[12] I. Rahutami, "Kerugian Ekonomi Akibat Cukai Ilegal Hasil Tembakau. Economy: cycle and anomaly," [Online], Available: http://ikasjourney.Blogspot.com, [Accessed: 28-Aug-2018]. 